\title{
Development of 'Darumadattan', a semidwarf lodging-resistant Tartary buckwheat cultivar, using gamma-ray irradiation
}

\author{
Akemi Shimizu'), Hiroyasu Yamaguchi ${ }^{1,2)}$, Konosuke Degi ${ }^{1,3)}$ and Toshikazu Morishita*1) \\ 1) NARO Institute of Crop Science, Radiation Breeding Division, 2425 Kamimurata, Hitachiomiya, Ibaraki 319-2293, Japan \\ 2) NARO Institute of Vegetable and Floriculture Science, 2-1 Fujimoto, Tsukuba, Ibaraki 305-8605, Japan \\ 3) Okinawa Prefectural Agricultural Research Center, Makabe, Itoman, Okinawa 901-0336, Japan
}

We developed a new cultivar of Tartary buckwheat (Fagopyrum tataricum Gaertn.), 'Darumadattan'. This is the first semidwarf Tartary buckwheat cultivar to be developed by mutation breeding using gamma-ray irradiation. In 1999, 100 dry seeds of the leading Japanese cultivar, 'Hokkai T8' (known at that time as 'Hokkei $\left.1^{\prime}\right)$, were gamma-ray-irradiated with a total dose of $500 \mathrm{~Gy}(25 \mathrm{~Gy} / \mathrm{h} \times 20 \mathrm{~h})$ at the Institute of Radiation Breeding (IRB), National Institute of Agrobiological Sciences, Hitachiomiya, Ibaraki, Japan. The seeds were sown in August 1999 in a field at IRB, and $\mathrm{M}_{2}$ seeds were collected from the eight individual plants that survived. In August 2000, $240 \mathrm{M}_{2}$ seeds were sown in a field, and one semidwarf plant was found. The line named 'IRBFT-20' developed from the selected plant was investigated for its semidwarf characteristic and genetic stability in 2001-2005. 'IRBFT-20' was submitted for registration in 2011 and registered as the cultivar 'Darumadattan' in 2013. This name was chosen because the plants resemble "Daruma dolls" and "dattan" means "Tartary" in Japanese. 'Darumadattan' is a highly lodging-resistant and high-yielding cultivar and is expected to be used as both a commercial cultivar and a crossing parent.

Key Words: Darumadattan, gamma-ray irradiation, lodging resistance, mutant, semidwarf, Tartary buckwheat.

\section{Introduction}

Since it contains large amounts of protein and minerals, buckwheat is well known as a healthy food. Specifically, the rutin content in Tartary buckwheat seeds is approximately 100 times that in the seeds of common buckwheat (Fagopyrum esculentum Moench) (Morishita et al. 2006). Although buckwheat is consumed in Japan, Tartary buckwheat is unpopular because of its bitter taste (Kawakami et al. 1995). The bitterness of Tartary buckwheat derives from the presence of three bitter compounds, quercetin and uncertain F3 and F4 compounds (Kawakami et al. 1995). Quercetin, a bitter compound, is produced from the degradation of rutin by rutinosidase which catalyze rutin to quercetin and rutinose (Yasuda et al. 1992). However, the trace-rutinosidase cultivar 'Manten-Kirari' has overcome the defects of bitterness in Tartary buckwheat (Suzuki et al. 2014), enabling the production of rutin-rich and high antioxidative activity foods (Ishiguro et al. 2016, Suzuki et al. 2015, 2019). Furthermore, the cultivar is promising as

Communicated by Ryo Ohsawa

Received April 8, 2020. Accepted June 29, 2020.

First Published Online in J-STAGE on August 28, 2020.

*Corresponding author (e-mail: tosikazu@affrc.go.jp) a good rutin resource (Morishita et al. 2020b). Rutin is commonly known as a functional component in Tartary buckwheat and has biological functions, such as antihypertension activity (Matsubara et al. 1985); the reduction of serum myeloperoxidase and cholesterol levels (Wieslander et al. 2011), mucosal symptoms, headaches, and tiredness (Wieslander et al. 2012); and the reduction of body weight, BMI (body mass index), and TBARS (2thiobarbituric acid reactive substances) levels (Nishimura et al. 2016). Because of these favorable traits, Tartary buckwheat has attracted attention in Japan and the breeding objective of improving yielding ability was discussed at a meeting of the Crop Science Society of Japan (Michiyama et al. 2015). Yet only a few Tartary buckwheat cultivars are available: 13 cultivars were registered in Japan from 2006 through 2020, and one cultivar has been under examination in May 2020 (Ministry of Agriculture, Forestry and Fisheries 2020). The cultivar 'Hokkai T8', the first major cultivar in Japan, showed high plant height and easy lodging (Honda et al. 2010). Later, the cultivar 'Hokuriku 4', which is $10 \mathrm{~cm}$ shorter than 'Hokkai T8', was developed (Ito et al. 2013). The plant height of 'Manten-Kirari' was similar to that of 'Hokkai T8' (Suzuki et al. 2014). As these available Tartary buckwheat cultivars are tall and lodge easily, lodging resistance is an important objective in 
Tartary buckwheat breeding (Hagiwara et al. 1999, Inoue et al. 2002).

Semidwarf traits have been promising material for lodging resistance in common buckwheat (Morishita et al. 2020a). As common and Tartary buckwheat have a similar plant shape, the semidwarf trait is expected to have the same effect in Tartary buckwheat. Dwarf and semidwarf genes have been reported in common buckwheat (Minami et al. 1999, Morishita et al. 2015, Ohnishi and Nagakubo 1982), but the practical semidwarf cultivars have not been developed. Available semidwarf trait have never been discovered in the genetic resources of Tartary buckwheat. However, semidwarf materials were developed by mutation breeding, and two semidwarf genes, $s d A$ and $s d B$ have been identified in Tartary buckwheat (Morishita et al. 2010). We developed a semidwarf cultivar 'Darumadattan' which belongs to the $s d A$ group. 'Darumadattan' was registered in 2013 (Ministry of Agriculture, Forestry and Fisheries 2013a). Here, we report on the breeding procedures and characteristics of 'Darumadattan'.

\section{Materials and Methods}

\section{Plant materials}

Tartary buckwheat cultivar 'Hokkai T8' was used as the original cultivar. In July 1999, 100 dry seeds of 'Hokkai
T8', known at that time as 'Hokkei 1' (before its registration as 'Hokkai T8'), were acutely gamma-ray-irradiated with a total dose of $500 \mathrm{~Gy}(25 \mathrm{~Gy} / \mathrm{h} \times 20 \mathrm{~h})$ in the gamma room of the Institute of Radiation Breeding (IRB) at the National Institute of Agrobiological Sciences (Existing NARO Institute of Crop Science, Radiation Breeding Division), Hitachiomiya, Ibaraki, Japan.

\section{Breeding}

The procedure is summarized in Table 1. All cultivation was carried out in the experimental field at IRB (Kamimurata, Hitachiomiya, Ibaraki, Japan; $140^{\circ} 24^{\prime} \mathrm{E}, 36^{\circ} 29^{\prime} \mathrm{N}$ ). The cultivation conditions are shown in Table 2. All irradiated $\mathrm{M}_{1}$ seeds were sown in August 1999. At harvest time in November 1999, eight plants of the $\mathrm{M}_{1}$ generation had survived, and $\mathrm{M}_{2}$ seeds were collected from them individually. Thirty $M_{2}$ seeds from each $M_{1}$ plant were sown as individual lines in August 2000. One semidwarf $\mathrm{M}_{2}$ plant was found and named 'R-21-8'. Its progeny was separated into two distinguishable lines (with or without red leaves) during fixation and confirmation at the $\mathrm{M}_{3}$ generation in 2001. These lines were named 'R-21-8-1' and 'R-21-8-2' in the $\mathrm{M}_{4}$ generation. However, as these two lines showed no difference during cultivation in 2002, it seemed that the difference observed in 2001 was caused by environmental factors. As 'R-21-8-1' yielded no seeds, 'R-21-8-2' was

Table 1. Breeding process of cultivar 'Darumadattan'

\begin{tabular}{|c|c|c|c|c|c|c|c|c|c|c|}
\hline Year & 199 & & 2000 & 2001 & 2002 & 2003 & $\begin{array}{l}2004 \\
2005\end{array}$ & 2006 & $\begin{array}{l}2007 \\
2008\end{array}$ & 2013 \\
\hline $\begin{array}{l}\text { Breeding } \\
\text { procedure }\end{array}$ & $\begin{array}{l}\text { Acute } 500 \text { Gy } \\
\text { irradiation for } \\
\text { dry seeds }\end{array}$ & Propagation & $\begin{array}{c}\text { Individual } \\
\text { selection }\end{array}$ & $\begin{array}{l}\text { Fixation and } \\
\text { confirmation }\end{array}$ & $\begin{array}{l}\text { Fixation and } \\
\text { confirmation }\end{array}$ & $\begin{array}{c}\text { Line } \\
\text { selection }\end{array}$ & $\begin{array}{c}\text { Propagation } \\
\text { of seeds }\end{array}$ & $\begin{array}{c}\text { Performance } \\
\text { test and } \\
\text { propagation } \\
\text { of seeds }\end{array}$ & $\begin{array}{c}\text { Performance } \\
\text { test }\end{array}$ & Registration \\
\hline $\begin{array}{l}\text { Number of } \\
\text { materials }\end{array}$ & $\begin{array}{c}100 \text { seeds } \\
\left(\mathrm{M}_{0}\right)\end{array}$ & 100 seeds & $\begin{array}{c}8 \text { lines, } \\
30 \text { seeds/line }\end{array}$ & 1 line & 2 lines & 2 lines & 1 line & 1 line & 1 line & 1 line \\
\hline $\begin{array}{l}\text { Number of } \\
\text { selections }\end{array}$ & $\begin{array}{c}100 \text { seeds } \\
\left(\mathrm{M}_{1}\right)\end{array}$ & $\begin{array}{c}8 \text { plants } \\
\text { survived }\end{array}$ & 1 plant & $\begin{array}{c}2 \text { separated } \\
\text { lines }\end{array}$ & 2 lines & 1 line & & & & \\
\hline Generation & $\mathrm{M}_{0}$ and $\mathrm{M}_{1}$ & $\mathrm{M}_{2}$ & $\mathrm{M}_{3}$ & $\mathrm{M}_{4}$ & $\mathrm{M}_{5}$ & $\mathrm{M}_{6}$ & $\mathrm{M}_{7}$ and $\mathrm{M}_{8}$ & & & \\
\hline Name & & & R-21-8 & $\begin{array}{l}\text { R-21-8-1 } \\
\text { R-21-8-2 }\end{array}$ & $\begin{array}{l}\text { R-21-8-1 } \\
\text { R-21-8-2 }\end{array}$ & $\mathrm{R}-21-8-2$ & IRBFT-20 & IRBFT-20 & IRBFT-20 & Darumadattan \\
\hline
\end{tabular}

Table 2. Cultivation conditions in Ibaraki (IRB)

\begin{tabular}{|c|c|c|c|c|c|c|c|c|}
\hline \multirow{2}{*}{ Purpose } & \multirow{2}{*}{ Year } & \multirow{2}{*}{$\begin{array}{l}\text { Number of } \\
\text { replications }\end{array}$} & \multirow{2}{*}{ Area $\left(\mathrm{m}^{2}\right)$} & \multirow{2}{*}{$\begin{array}{l}\text { Interrow space } \\
\qquad(\mathrm{cm})\end{array}$} & \multirow{2}{*}{$\begin{array}{l}\text { Seeding density } \\
\quad\left(\text { seeds } / \mathrm{m}^{2}\right)\end{array}$} & \multicolumn{3}{|c|}{ Fertilizer (kg/a) } \\
\hline & & & & & & $\mathrm{N}$ & $\mathrm{P}_{2} \mathrm{O}_{5}$ & $\mathrm{~K}_{2} \mathrm{O}$ \\
\hline Selection & 1999 to 2005 & 1 & - & 60 & 26 & 0.26 & 0.26 & 0.26 \\
\hline Performance test & 2006 to 2008 & 2 & 4.8 & 60 & 26 & 0.28 & 0.28 & 0.28 \\
\hline $\begin{array}{l}\text { Seeding density } \\
\text { test }\end{array}$ & 2006 & 2 & 4.8 & $\begin{array}{l}30 \\
30 \\
30 \\
60 \\
60 \\
60\end{array}$ & $\begin{array}{r}52 \\
104 \\
208 \\
26 \\
52 \\
104\end{array}$ & 0.28 & 0.28 & 0.28 \\
\hline $\begin{array}{l}\text { Heavy fertilizer } \\
\text { application test }\end{array}$ & 2006 & 2 & 4.8 & $\begin{array}{l}60 \\
30\end{array}$ & $\begin{array}{l}26 \\
52\end{array}$ & 1.40 & 1.40 & 1.40 \\
\hline
\end{tabular}


selected in 2003 at $\mathrm{M}_{6}$. At the $\mathrm{M}_{7}$ generation, grown in 2004, the selected line was named 'IRBFT-20', and seeds of 'IRBFT-20' were propagated for subsequent performance test from 2004 to 2006.

\section{Performance tests at the IRB in Ibaraki}

Performance tests for agronomic characteristics were carried out in the experimental field at IRB in 2006-2008. Cultivation conditions for the tests are shown in Table 2. Fertilizer containing $\mathrm{N}, \mathrm{P}_{2} \mathrm{O}_{5}$ and $\mathrm{K}_{2} \mathrm{O}$ at $0.26,0.26$, and $0.26 \mathrm{~kg} / \mathrm{a}$, respectively, was applied in 1999-2005 and with $0.28,0.28$, and $0.28 \mathrm{~kg} / \mathrm{a}$, respectively, was applied in 2006-2008. Characteristics were evaluated according to the Test Guidelines of Buckwheat (Ministry of Agriculture, Forestry and Fisheries 2013b). Degree of lodging was determined by observation; no lodging was 0 and completely lodged (lying completely flat) was 5 . Values 1 to 4 were divided equally between 0 and 5 .

\section{Seeding density and heavy fertilizer application tests at the IRB in Ibaraki}

Seeding density and heavy fertilizer application tests were carried out in 2006. Cultivation conditions for the tests are shown in Table 2. Standard fertilizer containing N, $\mathrm{P}_{2} \mathrm{O}_{5}$ and $\mathrm{K}_{2} \mathrm{O}$ at $0.28,0.28$, and $0.28 \mathrm{~kg} / \mathrm{a}$, respectively, was applied and heavy fertilizer, 5 times the standard, containing $1.40,1.40$, and $1.40 \mathrm{~kg} / \mathrm{a}$, respectively, was applied. Characteristics were evaluated according to performance tests.

\section{Performance tests in Hokkaido}

In 2009, a performance test was carried out in the experimental field at Memuro Upland Farming Research Division, Hokkaido Agricultural Research Center (HARC), NARO (Shinsei, Memuro, Kasai-gun, Hokkaido, Japan; $\left.143^{\circ} 03^{\prime} \mathrm{E}, 42^{\circ} 55^{\prime} \mathrm{N}\right)$. Seeds were sown on June 4 under the following conditions: plot size, $2.4 \mathrm{~m}^{2}$; seeding density, 66.7 seeds $/ \mathrm{m}^{2}$; row spacing, $60 \mathrm{~cm} ; 2$ replications. Fertilizer containing $\mathrm{N}, \mathrm{P}_{2} \mathrm{O}_{5}, \mathrm{~K}_{2} \mathrm{O}$ and $\mathrm{MgO}$ at $0.18 \mathrm{~kg} / \mathrm{a}, 0.72 \mathrm{~kg} / \mathrm{a}$, $0.42 \mathrm{~kg} / \mathrm{a}$ and $0.15 \mathrm{~kg} / \mathrm{a}$, respectively was applied. Agronomic characteristics were evaluated according to the Test Guidelines of Buckwheat (Ministry of Agriculture, Forestry and Fisheries 2013b).

\section{Performance tests in Nagano}

In 2014, a performance test was carried out in the experimental field at the Nagano Vegetable and Ornamental Crops Experimental Station (Souga, Shiojiri, Nagano, Japan; $\left.137^{\circ} 56^{\prime} \mathrm{E}, 36^{\circ} 6^{\prime} \mathrm{N}\right)$. Seeds were sown on August 4 under the following conditions: plot size, $7.2 \mathrm{~m}^{2}$; seeding density, 150 seeds $/ \mathrm{m}^{2}$; row spacing, $30 \mathrm{~cm} ; 2$ replications. Characteristics were evaluated according to the guidelines of Nagano Prefecture (Nagano Prefecture 2010).

\section{Rutin analysis}

Seeds of plants from the sowing density and heavy fertil- izer application tests were used. The rutin content of 'IRBFT-20' and 'Hokkai T8' seeds were determined using the method of Morishita et al. (2007).

\section{Analysis of variance (ANOVA)}

ANOVA was performed using the programs Excel (Microsoft Co., USA) and Excel statistics (Social Survey Research Information Co., LTD., Japan).

\section{Wind data}

Data for wind velocity was obtained from the website of the Japan Meteorological Agency (Japan Meteorological Agency 2020). Before 2007, maximum instantaneous wind velocity was not published. The data for Ibaraki was obtained from Hitachiomiya in 2008. The data of Nagano was obtained from Matsumoto Imai, near Shiojiri, in 2014. The data for Hokkaido was obtained from the observed values at Memuro Upland Farming Research Division, HARC, NARO.

\section{Application for registration}

'IRBFT-20' was submitted for registration in 2011 under the name 'Darumadattan'. In 2013, 'Darumadattan' was officially registered as a cultivar of Tartary buckwheat with the Ministry of Agriculture, Forestry and Fisheries (Ministry of Agriculture, Forestry and Fisheries 2013a). The name 'Darumadattan' was derived from "Daruma doll", which the plants resemble, and "dattan", meaning "Tartary" in Japanese.

\section{Results}

\section{Performance tests}

The results of performance tests, ANOVA and wind velocity during performance tests are shown in Tables 3, 4 and in Fig. 1, respectively. In Ibaraki, before maturing, there were a few days with strong wind before maturity in 2008. 'Darumadattan' plants were shorter than 'Hokkai T8' by approximately $50 \mathrm{~cm}$, and their growing period was longer by 6 days in 2006 and 2008, and 4 days in 2007. The number of nodes on the main stem of 'Darumadattan' exceeded that of 'Hokkai T8' but no significant difference was observed. The difference in seed yield between 'Darumadattan' and 'Hokkai T8' was not significant and varied with the cultivation year. Both 'Darumadattan' and 'HokkaiT8' can achieve high yield in Ibaraki. The 1000 seed weight was significantly higher in 'Hokkai T8' than in 'Darumadattan'.

In Hokkaido, calm days prevailed during cultivation. 'Darumadattan' plants were shorter than 'Hokkai T8' by approximately $110 \mathrm{~cm}$, and their main stems were significantly thicker. The degree of lodging of 'Darumadattan' was very low. The seed yield and 1000 seed weight were higher in 'Hokkai T8' than in 'Darumadattan'. Other characteristics were similar in both cultivars.

In Nagano, there were many days with strong wind 
Table 3. Results of performance test

\begin{tabular}{|c|c|c|c|c|c|c|c|c|c|c|c|c|c|c|c|c|c|c|c|c|}
\hline \multirow{2}{*}{ Place } & \multirow{2}{*}{ Year } & \multirow{2}{*}{$\begin{array}{c}\text { Sowing } \\
\text { time } \\
\text { month. } \\
\text { day }\end{array}$} & \multicolumn{2}{|c|}{$\begin{array}{l}\text { Flowering time } \\
\text { month.day }\end{array}$} & \multicolumn{2}{|c|}{$\begin{array}{l}\text { Time of maturity } \\
\text { month.day }\end{array}$} & \multicolumn{2}{|c|}{$\begin{array}{l}\text { Plant height } \\
\mathrm{cm}\end{array}$} & \multicolumn{2}{|c|}{$\begin{array}{c}\text { Number of nodes } \\
\text { on main stem } \\
\text { No./plant }\end{array}$} & \multicolumn{2}{|c|}{$\begin{array}{c}\text { Number of } \\
\text { primary branches } \\
\text { No./plant }\end{array}$} & \multicolumn{2}{|c|}{$\begin{array}{l}\text { Degree of } \\
\text { lodging }^{a}\end{array}$} & \multicolumn{2}{|c|}{$\begin{array}{l}\text { Stem diameter } \\
\mathrm{mm}\end{array}$} & \multicolumn{2}{|c|}{ Seed yield kg/a } & \multicolumn{2}{|c|}{$\begin{array}{l}1000 \text { seed } \\
\text { weight g }\end{array}$} \\
\hline & & & $\begin{array}{c}\text { Daruma- } \\
\text { dattan }\end{array}$ & $\begin{array}{l}\text { Hokkai } \\
\text { T8 }\end{array}$ & $\begin{array}{c}\text { Daruma- } \\
\text { dattan }\end{array}$ & $\begin{array}{l}\text { Hokkai } \\
\text { T8 }\end{array}$ & $\begin{array}{c}\text { Daruma- } \\
\text { dattan }\end{array}$ & $\begin{array}{l}\text { Hokkai } \\
\text { T8 }\end{array}$ & $\begin{array}{c}\text { Daruma- } \\
\text { dattan }\end{array}$ & $\begin{array}{l}\text { Hokkai } \\
\text { T8 }\end{array}$ & $\begin{array}{c}\text { Daruma- } \\
\text { dattan }\end{array}$ & $\begin{array}{l}\text { Hokkai } \\
\text { T8 }\end{array}$ & $\begin{array}{c}\text { Daruma- } \\
\text { dattan }\end{array}$ & $\begin{array}{l}\text { Hokkai } \\
\text { T8 }\end{array}$ & $\begin{array}{c}\text { Daruma- } \\
\text { dattan }\end{array}$ & $\begin{array}{l}\text { Hokkai } \\
\text { T8 }\end{array}$ & $\begin{array}{c}\text { Daruma- } \\
\text { dattan }\end{array}$ & $\begin{array}{l}\text { Hokkai } \\
\text { T8 }\end{array}$ & $\begin{array}{c}\text { Daruma- } \\
\text { dattan }\end{array}$ & $\begin{array}{c}\text { Hokkai } \\
\text { T8 }\end{array}$ \\
\hline \multirow{4}{*}{ Ibaraki } & 2006 & 8.18 & 9.24 & 9.22 & 11.10 & 11.04 & 60 & 138 & 22.2 & 20.7 & 7.3 & 7.0 & 0 & 3 & - & - & 17.6 & 17.7 & 15.2 & 19.0 \\
\hline & 2007 & 8.28 & 10.05 & 10.01 & 11.24 & 11.20 & 53 & 115 & 20.1 & 18.6 & 6.9 & 6.4 & - & - & - & - & 13.8 & 18.1 & 16.6 & 21.4 \\
\hline & 2008 & 8.20 & 9.26 & 9.22 & 11.20 & 11.14 & 44 & 73 & 17.5 & 15.5 & 7.0 & 6.0 & 0 & 3 & - & - & 7.8 & 9.5 & 15.5 & 20.6 \\
\hline & Average & 8.22 & 9.28 & 9.25 & 11.18 & 11.13 & 52 & 109 & 19.9 & 18.3 & 7.1 & 6.5 & 0 & 3 & - & - & 13.1 & 15.1 & 15.8 & 20.3 \\
\hline Hokkaido & 2009 & 6.04 & 7.19 & 7.17 & 9.10 & 9.09 & 67 & 179 & 20.2 & 19.0 & 5.9 & 4.6 & 0 & 4 & 8.5 & 6.9 & 19.3 & 36.9 & 13.6 & 20.0 \\
\hline Nagano & 2014 & 8.04 & 9.11 & 9.09 & $10.29^{b}$ & $10.29^{b}$ & 56 & 153 & 16.9 & 17.6 & 5.1 & 4.4 & 0 & 3 & - & - & 28.8 & 19.8 & 14.9 & 19.7 \\
\hline
\end{tabular}

There was no replication of 'Darumadattan' in 2007 due to moisture damage.

-: No data.

${ }^{a} 0$ none- 5 completely lodgied.

${ }^{b}$ Damage by frost on October 29 prevented further maturation.

Table 4. ANOVA of performance test

\begin{tabular}{lccccccc}
\hline \hline Place & Factor & Plant height & $\begin{array}{c}\text { Number of nodes } \\
\text { on main stem }\end{array}$ & $\begin{array}{c}\text { Number of } \\
\text { primary branches }\end{array}$ & Seed yield & $\begin{array}{c}\text { Stem diameter } \\
\text { 1000 seed } \\
\text { weight }\end{array}$ \\
\hline \multirow{3}{*}{ Ibaraki $^{a}$} & Cultivar (C) & $* *$ & NS & NS & NS & - & $* *$ \\
\cline { 2 - 7 } & Year (Y) & $* *$ & NS & NS & NS & - & NS \\
\hline Hokkaido & C $\times$ Y & $*$ & NS & NS & NS & - & $*$ \\
\hline Nagano & Cultivar & $* *$ & NS & NS & NS & $*$ & $* *$ \\
\hline
\end{tabular}

${ }^{a}$ Analysis of 2006 and 2008.

*,**, NS: significantly different at the 0.05 and 0.01 levels and non-significant at the 0.05 level.

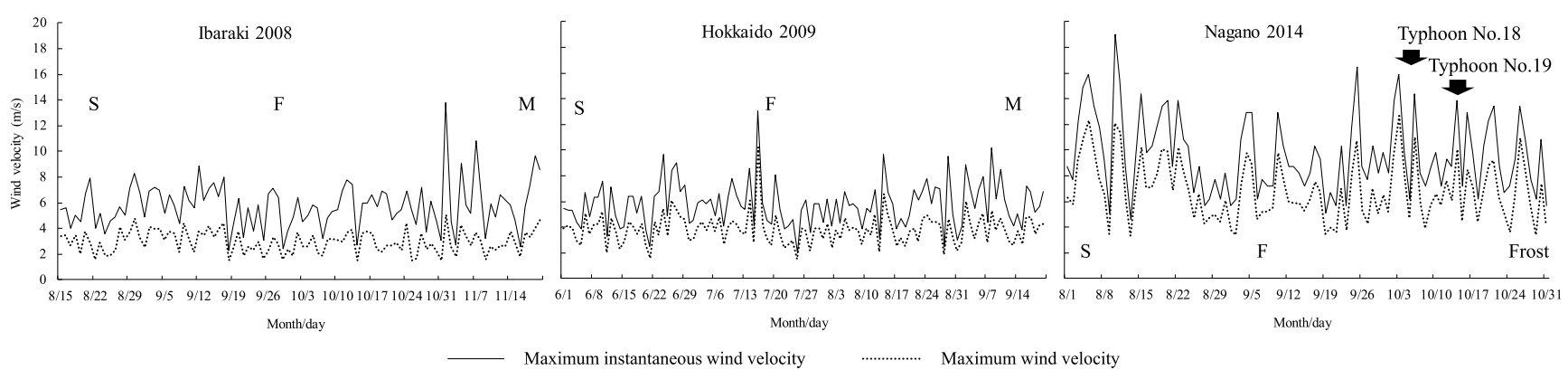

Fig. 1. The wind velocity during cultivation periods. The wind velocity of places during cultivation period. Wind velocity data of Ibaraki and Nagano were obtained from the web site of Japan Meteorological Agency (JMA) and that of Hokkaido was obtained from the observed values at Memuro Upland Farming Research Division HARC NARO. S: seeding, F: flowering, M: maturity.

during the growing period and two typhoons hit during the maturing period. 'Darumadattan' plants were shorter than 'Hokkai T8' by approximately $100 \mathrm{~cm}$. Their time of flowering was similar, but both cultivars were damaged before maturity by frost on October 29, making it impossible to determine the time of maturity. The seed yield of 'Darumadattan' was obviously higher than that of 'Hokkai T8'. The 1000 seed weight was higher in 'Hokkai T8' than in 'Darumadattan'. 'Hokkai T8' lodged in strong wind, but 'Darumadattan' did not lodge.

\section{Seeding density and heavy fertilizer application tests}

The results of seeding density and heavy fertilizer application tests are shown in Table 5. In seeding density tests, 'Darumadattan' plants were approximately 50\% shorter than 'Hokkai T8' plants, regardless of the interrow space or seeding density. The degree of lodging of 'Darumadattan' was very low, regardless of the interrow space or seeding density. Although no significant difference in seed yield was observed among cultivation treatments, the following differences were observed. At the same seeding density, reducing the interrow space from $60 \mathrm{~cm}$ to $30 \mathrm{~cm}$ caused an increase in the yield of 'Darumadattan' but not in 'Hokkai T8'. At a given row spacing, increasing the seeding density did not increase yield in either cultivar. The rutin content of 'Darumadattan' was significantly lower than that of 'Hokkai T8' in all treatment. On the other hand, the differences of the rutin content between treatment were not significant. Even when the amount of fertilizer was increased $(\times 5)$ in the heavy fertilizer application test, 'Darumadattan' 


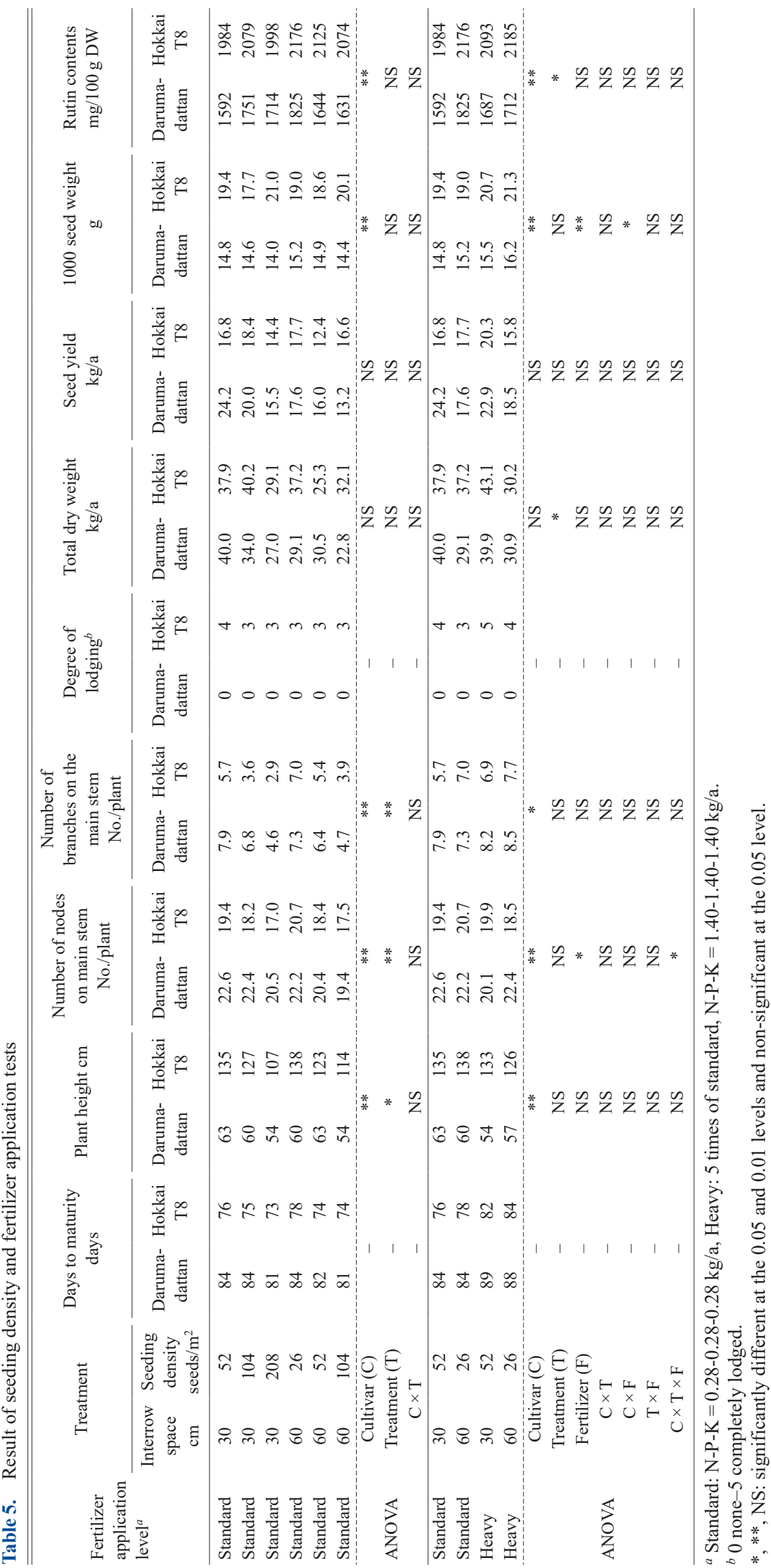


showed very strong lodging resistance. Heavy fertilization increase neither plant height nor seed yield, but resulted in an increase in the 1000 seed weight and a decrease in the number of nodes and rutin content in both cultivars.

\section{Discussion}

In this study, we found that 'Darumadattan' plants were shorter than 'Hokkai T8' plants (Tables 3, 5). The main stem length (the sum of the internode lengths) was also shorter in 'Darumadattan' (data not shown); this confirms the results of Kasajima et al. (2012), who measured the main stem length in 'Darumadattan' (IRBFT-20, in the test) plants when the line was in the process of registration. The numbers of nodes on the main stems of the two cultivars were similar (Tables 3, 4). The internode elongation pattern in 'Darumadattan' (IRBFT-20) was examined in detail by Kasajima et al. (2013). Since each internode was shorter in 'Darumadattan', the main stem was also shorter than in the original cultivar. On the other hand, although 'Darumadattan' revealed latter maturity and lower 1000 seed weight than those of 'Hokkai T8', the effect of the semidwarf gene for these characteristics is unknown. As the semidwarf trait in 'Darumadattan' ('IRBFT-20') is controlled by a single nuclear recessive gene $s d A$ (Morishita et al. 2010), this trait could be easily introduced into other cultivars by crossing using the hot-water emasculation method (Mukasa et al. 2007). A further semidwarf cultivar is currently under development (Suzuki 2019).

In the seeding density and heavy fertilizer application tests, the seed yield of 'Darumadattan' was higher than that of 'Hokkai T8' except when the seeding density was 104 seeds $/ \mathrm{m}^{2}$ and the interrow space was $60 \mathrm{~cm}$ (Table 5). A fertilizer application test conducted in Hokkaido by Kasajima et al. (2012) resulted in no considerable differences in seed yield between the two cultivar genotypes.
Depending on the cultivation year and site, the seed yield of 'Darumadattan' was sometimes lower and sometimes higher than that of 'Hokkai T8' (Tables 3, 5). Morishita et al. (2006) reported a significant correlation between yield and plant height in Tartary buckwheat cultivars. Contrary to our expectations based on their results, 'Darumadattan' did not show a decreased yield (except when it was tested in Hokkaido) despite its reduced height. Furthermore, 'Darumadattan' showed sufficient yield in each test location for June and August seeding, and thus the semidwarf trait of 'Darumadattan' seemed to be available breeding material for various locations.

The main stem diameter was $8.5 \mathrm{~mm}$ in 'Darumadattan' and $6.9 \mathrm{~mm}$ in 'Hokkai T8' (Table 3). Hagiwara et al. (1999) showed that the correlation coefficient (negative) between the main stem diameter at the basal internode and the lodging degree was the second highest after the correlation between the main stem length and lodging resistance and was significant in 89 strains of Tartary buckwheat collected from around the world. In our study, the main stem of 'Darumadattan' was significantly thicker than that of 'Hokkai T8', the original cultivar. The increased main stem diameter is one of the reasons for 'Darumadattan' being a highly lodging-resistant cultivar.

As mentioned above, the lodging resistance of 'Darumadattan' is extremely strong (Tables $\mathbf{3}, \mathbf{5}$, Fig. 2). Before the typhoon No. 18 in 2014, both 'Darumadattan' and 'Hokkai T8' were standing upright (Fig. 2A). However, after the typhoon No. 18, 'Darumadattan' plants were still standing upright (Fig. 2B), while 'Hokkai T8' plants were not (Fig. 2B). From photograph (Fig. 2), the lower leaves of 'Darumadattan' are large and expansive widely, while the upper leaves are small. It is thought that the plant shape of a low center of gravity position contributed to lodging resistance. The result of the performance test in Nagano provides further evidence of the strong lodging resistance
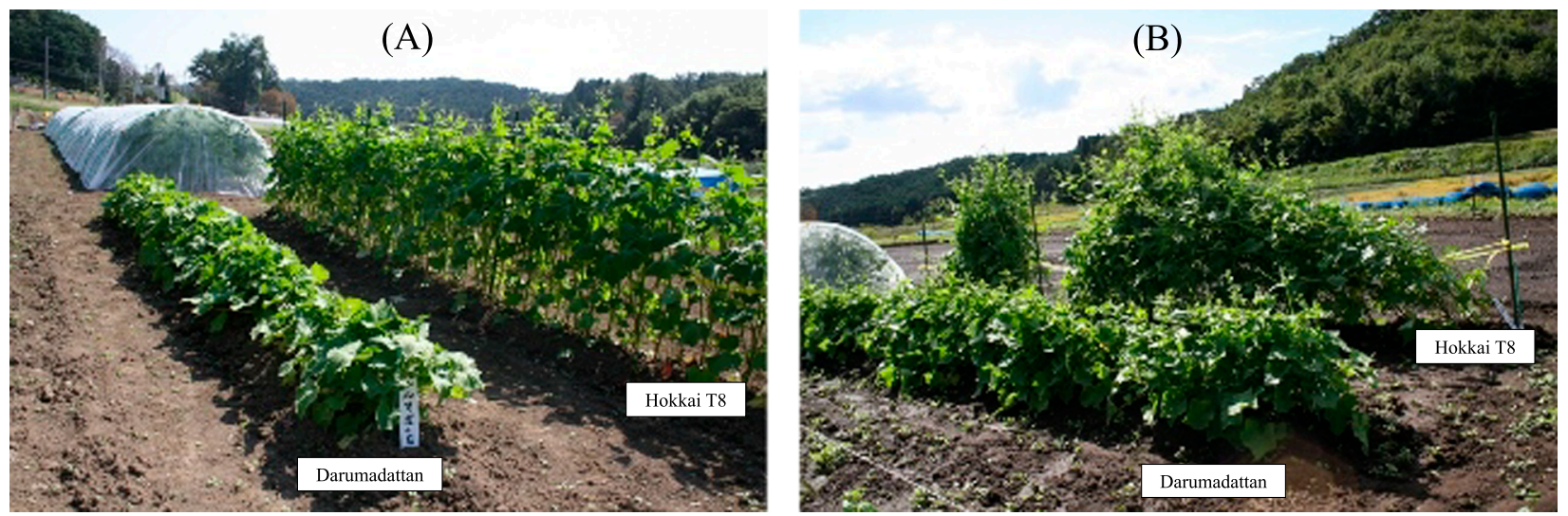

Fig. 2. Photograph of 'Darumadattan' and 'Hokkai T8' before and after typhoon. Comparison of the new cultivar 'Darumadattan' and the original cultivar 'Hokkai T8'. Photograph (A) was taken on September 30, 2014 (before typhoon No. 18, maximum instantaneous wind velocity was $16.5 \mathrm{~m} / \mathrm{s}$ on October 6). Photograph (B) was taken on October 7, 2014 (after typhoon No. 18). 'Hokkai T8' lodged (the supporting cord was stretched; (B), right), whereas 'Darumadattan' did not (B). Photographs were taken in the field at the IRB in Ibaraki. Fertilizer applied with N, $\mathrm{P}_{2} \mathrm{O}_{5}$ and $\mathrm{K}_{2} \mathrm{O}$ at $0.28,0.28$, and $0.28 \mathrm{~kg} / \mathrm{a}$, respectively. 
of 'Darumadattan', since no lodging occurred despite strong winds, typhoon No. 18 and 19 being experienced in Nagano (Fig. 1). On the other hand, in Hokkaido in 2009, as there was no typhoon damage during the cultivation period, the season appeared to be favorable for 'Hokkai T8'.

In this report, we have described the development of a semidwarf cultivar 'Darumadattan' from 100 seeds of 'Hokkai T8' irradiated by 500 Gy of gamma rays. In addition, other gamma ray irradiation ( $0-500 \mathrm{~Gy})$ to two genetic resources and three breeding lines were also performed (Morishita et al. 2001). Totally, about 4,000 seeds were provided and two semidwarf materials, one being 'IRBFT-6' from 'Pontivy' irradiated by 50 Gy and the other 'IRBFT-20' (Darumadattan) from 'Hokkei 1' (Hokkai T8) (Morishita et al. 2010). Consequently, a few thousand seeds are necessary for inducing desired material by mutation breeding.

As lodging reduces the Tartary buckwheat harvest, lodging resistance is a desired agronomic trait in Tartary buckwheat cultivation (Hagiwara et al. 1999, Inoue et al. 2002). The cultivar reported here is the first promising cultivar with lodging resistance.

\section{Author Contribution Statement}

AS, HY, KD and TM designed this study and bred 'Darumadattan'. TM conducted the gamma ray irradiation and select the semidwarf mutant. AS and TM carried out performance tests and component analysis. AS and TM drafted the manuscript. All authors read and approved the final manuscript.

\section{Acknowledgments}

We extended our sincere thanks to Mr. H. Maruyama at the Nagano Vegetable and Ornamental Crops Experimental Station for kindly providing the data from the performance test in Nagano. We also thank Mr. H. Kuwahara and Mr. Y. Shimane at IRB for their technical assistance in the field. This work was supported in part by the Budget for Nuclear Research of the Ministry of Education, Culture, Sports, Science and Technology, based on screening and counseling by the Atomic Energy Commission of Japan.

\section{Literature Cited}

Hagiwara, M., H. Izusawa, N. Inoue and T. Matano (1999) Varietal differences of shoot growth characters related to lodging in Tartary buckwheat. Fagopyrum 16: 67-72.

Honda, Y., Y. Mukasa, T. Suzuki, S. Yokota, K. Nakatsuka, M. Kimura, M. Kawakatsu and M. Agatuma (2010) Breeding and characteristics of a Tartary buckwheat cultivar, "Hokkai T No. 8". Res. Bull. Natl. Agric. Res. Cent. for Hokkaido Reg. 192: 1-13.

Inoue, N., E. Ishida and K. Fujita (2002) Relationship between lodging tolerance and morphological characteristics of root system in
Tartary buckwheat. Jpn. J. Crop Sci. 71 (Ext. I): 114-115.

Ishiguro, K., T. Morishita, J. Ashizawa, T. Suzuki and T. Noda (2016) Antioxidative activities in rutin rich noodles and cookies made with a trace rutinosidase variety of Tartary buckwheat (Fagopyrum tataricum Gaertn.), 'Manten-Kirari'. Food Sci. Technol. Res. 22: $557-562$.

Ito, S., R. Ohsawa, T. Baba, E. Aoki, T. Tsutumi, A. Arakawa and K. Hayashi (2013) A new Tartary buckwheat variety, "Hokuriku 4". Bull. NARO Agri. Res. Cent. 18: 1-13.

Japan Meteorological Agency (2020) Weather, Climate \& Earthquake Information (http://www.jma.go.jp/jma/menu/menureport.html) (accessed May 25, 2020).

Kasajima, S., H. Itoh, H. Yoshida, T. Suzuki, Y. Mukasa, T. Morishita and A. Shimizu (2012) Growth, yield, and dry matter production of a gamma ray-induced semi dwarf mutant of Tartary buckwheat. Fagopyrum 29: 7-12.

Kasajima, S., A. Endo, H. Itoh, H. Yoshida, T. Suzuki, Y. Mukasa, T. Morishita and A. Shimizu (2013) Internode elongation patterns in semi dwarf and standard-height genotypes of Tartary buckwheat. Fagopyrum 30: 15-18.

Kawakami, A., H. Kayahara and A. Ujihara (1995) Properties and elimination of bitter components derived from Tartary buckwheat (Fagopyrum tataricum) flour. Nippon Shokuhin Kagaku Kogaku Kaishi 42: 892-898.

Matsubara, Y., H. Kumamoto, Y. Iizuka, T. Murakami, K. Okamoto, H. Miyake and K. Yokoi (1985) Structure and hypotensive effect of flavonoid glycosides in Citrus unshiu peelings. Agric. Biol. Chem. 49: 909-914.

Michiyama, H., H. Sugimoto, H. Hayashi, T. Morishita, T. Tetsuka, M. Katsuta, T. Hara and S. Kasajima (2015) Information: A report on a small meeting on the "Possibility of cultivation of Tartary buckwheat in Japan”. Jpn. J. Crop Sci. 84: 218-219.

Minami, M., A. Ujihara and C.G. Campbell (1999) Morphology and inheritance of dwarfism in common buckwheat line, G410, and its stability under different growth conditions. Breed. Sci. 49: 27-32.

Ministry of Agriculture, Forestry and Fisheries (2013a) Plant Variety Protection. DARUMADATTAN (http://www.hinshu2.maff.go.jp/ vips/cmm/apCMM112.aspx?TOUROKU_NO=22633\&bLANGU $\mathrm{AGE}=$ English) (accessed May 25, 2020).

Ministry of Agriculture, Forestry and Fisheries (2013b) Test guideline of buckwheat (http://www.hinshu2.maff.go.jp/info/sinsakijun/ kijun/1274.pdf) (accessed March 10, 2020).

Ministry of Agriculture, Forestry and Fisheries (2020) Searching plant variety (http://www.hinshu2.maff.go.jp/vips/cmm/apCMM110. aspx?MOSS=1) (accessed March 10, 2020).

Morishita, T., H. Yamaguchi and K. Degi (2001) The dose response and mutation induction by gamma ray in buckwheat. Proc. 8th Int. Symp. Buckwheat 334-343.

Morishita, T., H. Yamaguchi, K. Degi and T. Tetsuka (2006) Agronomic characters and chemical component of grains of Tartary buckwheat. Jpn. J. Crop Sci. 75: 335-344.

Morishita, T., H. Yamaguchi and K. Degi (2007) The contribution of polyphenols to antioxidative activity in common buckwheat and Tartary buckwheat grain. Plant Prod. Sci. 10: 99-104.

Morishita, T., Y. Mukasa, T. Suzuki, A. Shimizu, H. Yamaguchi, K. Degi, J. Aii, Y. Hase, N. Shikazono, A. Tanaka et al. (2010) Characteristics and inheritance of the semidwarf mutants of Tartary buckwheat (Fagopyrum tataricum Gaertn.) induced by gamma ray and ion beam irradiation. Breed. Res. 12: 39-43.

Morishita, T., T. Suzuki and Y. Mukasa (2015) Characteristics of a novel 'semidwarf materials' in common buckwheat. Fagopyrum 
32: $9-14$

Morishita, T., T. Hara and T. Hara (2020a) Important agronomic characteristics of yielding ability in common buckwheat; ecotype and ecological differentiation, preharvest sprouting resistance, shattering resistance, and lodging resistance. Breed. Sci. 70: 39-47.

Morishita, T., K. Ishiguro, T. Noda and T. Suzuki (2020b) The effect of grain moisture contents on the roll milling characteristics of Tartary buckwheat cultivar 'Manten-Kirari'. Plant Prod. Sci. 23: 539-546.

Mukasa, Y., T. Suzuki and Y. Honda (2007) Emasculation of Tartary buckwheat (Fagopyrum tartaricum Gaertn.) using hot water. Euphytica 156: 319-326.

Nagano Prefecture (2010) Research guidelines for buckwheat. In: Guidelines for main crops, Nagano Prefecture.

Nishimura, M., T. Ohkawara, Y. Sato, H. Satoh, T. Suzuki, K. Ishiguro, T. Noda, T. Morishita and J. Nishihira (2016) Effectiveness of rutin-rich Tartary buckwheat (Fagopyrum tataricum Gaertn.) 'Manten-Kirari' in body weight reduction related to its antioxidant properties: A randomised, double-blind, placebocontrolled study. J. Funct. Foods 26: 460-469.

Ohnishi, O. and T. Nagakubo (1982) Population genetics of cultivated common buckwheat, Fagopyrum esculentum Moench. II. Frequency of dwarf mutants in Japanese populations. Jpn. J. Genet. 57: 641-650

Suzuki, T., T. Morishita, Y. Mukasa, S. Takigawa, S. Yokota, K. Ishiguro and T. Noda (2014) Breeding of 'Manten-Kirari', a non- bitter and trace-rutinosidase variety of Tartary buckwheat (Fagopyrum tataricum Gaertn.). Breed. Sci. 64: 344-350.

Suzuki, T., T. Morishita, S. Takigawa, T. Noda and K. Ishiguro (2015) Characterization of rutin-rich bread made with 'Manten-Kirari', a trace-rutinosidase variety of Tartary buckwheat (Fagopyrum tataricum Gaertn.). Food Sci. Technol. Res. 21: 733-738.

Suzuki, T. (2019) Breeding of 'Manten-Kirari', a non-bitter Tartary buckwheat variety. Breed. Res. 21: 137-140.

Suzuki, T., T. Morishita, S. Takigawa, T. Noda and K. Ishiguro (2019) Development of rutin-rich noodles using trace-rutinosidase variety of Tartary buckwheat (Fagopyrum tataricum Gaertn.) 'MantenKirari'. Food Sci. Technol. Res. 25: 915-920.

Wieslander, G., N. Fabjan, M. Vogrincic, I. Kreft, C. Janson, U. Spetz-Nyström, B. Vombergar, C. Tagesson, P. Leanderson and D. Norbäck (2011) Eating buckwheat cookies is associated with the reduction in serum levels of myeloperoxidase and cholesterol: A double blind crossover study in day-care center staffs. Tohoku J. Exp. Med. 225: 123-130.

Wieslander, G., N. Fabjan, M. Vogrincic, I. Kreft, B. Vombergar and D. Norbäck (2012) Effect of common and Tartary buckwheat consumption on mucosal symptoms, headache and tiredness: A double-blind crossover intervention study. J. Food Agric. Environ. 10: 107-110.

Yasuda, T., K. Masaki and T. Kashiwagi (1992) An enzyme degrading rutin in Tartary buckwheat seeds. J. Jpn. Soc. Food Sci. Technol. 39: 994-1000. 